\title{
Gorlin Sendromlu olgularda saptanan üç yeni PTCH1 varyantı
}

Detection of three new PTCH1 variants in patients with Gorlin Syndrome

\author{
Aslı Ece Solmaz Hüseyin Onay \\ Ege Üniversitesi Tıp Fakültesi, Tıbbi Genetik Anabilim Dalı, İzmir, Türkiye
}

\section{ÖZ}

Amaç: Gorlin Sendromu (OMIM \#109400), bazal hücreli karsinomalar (BHK), iskelet anomalileri ve çenede gözlenen çok sayıdaki kistlerle karakterize otozomal dominant kalıtımlı nadir bir hastalıktır. Gorlin Sendromunun \%50-85'inden PTCH1 genindeki mutasyonlar sorumludur. Bu çalışmada klinik olarak Gorlin Sendromu tanısı düşünülen hastalarda yapılmış $P T C H 1$ gen dizi analizlerinin retrospektif olarak değerlendirilmesi ve varyant saptanan hastalarda fenotip-genotip korelasyonu yapılması amaçlanmıştır.

Gereç ve Yöntem: Ege Üniversitesi Tıp Fakültesi Hastanesi Tıbbi Genetik Anabilim Dalı'na başvuran Gorlin Sendromu düşünülen dört hastanın $\mathrm{PTCH1}$ genindeki varyantlar ile klinik ve laboratuvar bulguları geriye dönük olarak incelenmiştir.

Bulgular: PTCH1 gen dizi analizi yapılan dört hastada üçü yeni olmak üzere dört farklı varyant saptanmıştır. Hastalardaki klinik bulguların sıklıkları ve dağılımı değerlendirildi.

Sonuç: Bu çalışma Türkiye'de yapılan Gorlin Sendromlu olgularda PTCH1 gen varyantlarının dağılımı ile ilgili ilk çalışma olup üç yeni varyant saptanmıştır. Saptanan varyantlar ve klinik bulgular ile fenotipgenotip korelasyonu değerlendirilmiştir.

Anahtar Sözcükler: Gorlin sendromu, PTCH1, mutasyon, genotip-fenotip korelasyonu.

\section{ABSTRACT}

Aim: Gorlin Syndrome (OMIM \# 109400) is a rare autosomal dominant disease characterized by basal cell carcinomas (RCC), skeletal abnormalities and multiple cysts observed in the jaw. Mutations in the PTCH1 gene are responsible for 50-85\% of Gorlin Syndrome. The aim of this study was to retrospectively evaluate PTCH1 gene sequence analysis in patients with clinically diagnosed Gorlin Syndrome and to delineate phenotype-genotype correlations.

Materials and Methods: Four patients who referred to the Ege University Medical Faculty Hospital Medical Genetics Department due to Gorlin Syndrome were considered with mutations in PTCH1 gene and clinical findings analyzed retrospectively.

Results: Four different mutations mutations (with three being novel) were detected in four patients who underwent PTCH1 gene sequence analysis. The frequency and distribution of clinical findings were evaluated.

Conclusion: This is the first study from Turkey investigating PTCH1 gene mutation spectrum in Gorlin Syndrome which were identified three novel mutations. Phenotype-genotype correlation was evaluated with mutations and clinical findings.

Keywords: Gorlin syndrome, PTCH1, mutation, genotype-phenotype correlation.

\footnotetext{
Sorumlu yazar: Aslı Ece Solmaz

Ege Üniversitesi Tıp Fakültesi, Tıbbi Genetik Anabilim Dalı,

İzmir, Türkiye

E-posta: as_ece@hotmail.com

Başvuru tarihi: 26.02.2020

Kabul tarihi: 22.09.2020
} 


\section{GíRiş}

Gorlin Sendromu (OMIM \#109400), Bazal Hücreli Nevus Sendromu ya da Gorlin Sendromu olarak da bilinen bazal hücreli karsinomalar (BHK), iskelet anomalileri ve çenede gözlenen çok sayıdaki kistlerle karakterize otozomal dominant kalıtımlı nadir bir hastalıktır. Hastalıkla ilişkili karakteristik kemik bulguları MÖ 2500-3000 yıllarından kalma iki Mısır iskeletinde gözlenmiştir (1). Sendrom ise 1960 yılında Dr. Gorlin ve Dr. Goltz tarafından bazal hücreli karsinom, çene kisti ve bifid kosta kliniği olan bir ailede tanımlanmıştır (2). Gorlin Sendromunun sıklığı toplumlar arası farklılık göstermektedir. Eski bir çalışmada 56000'de 1 sıklık bildirilirken daha güncel bir çalışmada 19000'de 1 kadar sık görülebildiği bildirilmiştir $(3,4)$. Hastaların bir kısmının tanı almadığı ve asıl sıklığın çok daha yüksek olduğu düşünülmektedir.

Hastalığın penetransı tam, ekspresivitesi ise değişkendir. Hastalığın tanısı için bir major bulgu ve mutasyon saptanması; iki major bulgu veya bir major bulgu ve iki minör bulgu varlığı gerekmektedir. Major bulgular: 1- İkiden fazla BHK ya da 20 yaş altında bir tane BHK öyküsünün olması, 2- Çenenin odontojenik keratokistleri (histolojik olarak kanıtlanmış), 3- Üç ya da daha fazla palmoplantar çukurlanma, 4Falx cerebri kalsifikasyonu, 5- Medulloblastom, 6Birinci derece akrabada Gorlin Sendromu tanısının olmasıdır. Minör bulgular: 1Makrosefali, 2- Bifid ya da birleşik kosta, 3İskelet anomalileri ve radyolojik anomaliler, 4Lenfomezenterik kist, 5- Over/kardiyak fibrom, 6Yarık dudak-damak ve 7- Göz anomalileridir (5).

Gorlin Sendromunun bugüne kadar belirlenmiş üç geni mevcuttur. Bunlar PTCH1, PTCH2 ve SUFU genleridir (6-8). Klinik olarak kriterleri karşılayan hastaların \%50-85'inde PTCH1 geninde, $\% 5$ 'inde ise SUFU geninde germline mutasyon saptanmaktadır $(9,10)$. PTCH2 geni yeni saptanan bir gen olup mutasyonu oldukça nadirdir (8). PTCH1 geni "Drosophila patched" geni homoloğu olup 9q22.3 lokusunda bulunmaktadır. Bu gen 1447 amino asit uzunluğunda bir glikoprotein kodlamaktadır (6). Patched-1 proteini Sonic Hedgehog (SHH) yolağında transmembran reseptörü görevi görmektedir (11).

Ülkemizde Gorlin Sendromlu PTCH1 varyantı taşıyan olguların bildirildiği tek olgu içeren yayınlar bulunmaktadır (12-14). Gorlin Sendromlu olgularda mutasyon spektrumu ve klinik bulguların değerlendirildiği yayın ise bulunmamaktadır. Bu çalışmada klinik olarak Gorlin Sendromu tanısı düşünülen hastalarda yapılmış $\mathrm{PTCH} 1$ gen dizi analizlerinin retrospektif olarak değerlendirilmesi ve varyant saptanan hastalarda fenotip-genotip korelasyonu yapılması amaçlanmıştır. Çalışmamız Türkiye'de PTCH1 varyant dağılımı ve klinik bulguların değerlendirildiği ilk çalışma olma özelliğindedir.

\section{GEREÇ VE YÖNTEM}

Ege Üniversitesi Tıp Fakültesi Tıbbi Genetik Anabilim Dalı'na başvuran ve klinik bulguları ile Gorlin Sendromu düşünülen dört hasta çalışmaya dahil edilmiştir. Hastaların hepsi MiSeq platformunda Illumina TruSight $^{\circledR}$ Cancer Sequencing Panel (Illumina, San Diego, CA) ile çalışılmıştır. PTCH1 geninde saptanan değişiklikler NM_000264 transkriptine göre T Exome Aggregation Consortium (ExAC)/ Genome Aggregation Database (gnomAD), Database of Short Genetic Variation (dbSNP), ClinVar, and Human Gene Mutation Database (HGMD) veritabanları ve SIFT, PolyPhen-2, Mutation Taster in silico programları ile değerlendirilmiştir. Varyant saptanan hastaların klinik ve laboratuvar bulguları geriye dönük olarak incelenmiştir. Çalışma için Ege Üniversitesi Tıp Fakültesi tıbbi araştırmalar etik kurulundan onay alınmıştır (Karar Nu:19-10.1T/12).

\section{BULGULAR}

Çalışmaya dört farklı aileden birer kişi alındı. Hastaların ikisi kadın, ikisi ise erkekti. Yaş ortalamaları 32,7 (20-49) olarak saptandı. En sık bulgu çenede kist olup, olguların tamamında mevcuttu. İkinci sıklıkta görülen bulgu üç olguda saptanan (\%75) falx cerebri kalsifikasyonuydu. Şekil-1'de Olgu 1'in falx cerebri kalsifikasyonu ve çene kistleri görülmektedir. Olguların yarısında (\%50) görülen bulgular; bazal hücreli karsinom, palmoplantar pit, gömülü dişler ve polidaktili idi. Olgu 2'de çok sayıda bifid kosta anomalisi, skolyoz, sağ humerus orta diafizer bölümde iki adet fokal rastlantısal benign lezyon (fibröz kortikal defekt) ve tek gözde doğuştan görme kaybı mevcuttu. Olgu 3'te ise çocukluk çağında geçirilmiş serebellar pilositik astrositom operasyonu bildirildi. Ayrıca tanı kriterlerinde yer almayan çoğunlukla yüz bölgesinde yerleşen çok sayıda nevus olgularda dikkat çekmekteydi. Tablo-1'de olguların klinik verileri gösterilmektedir. Olgulardan sadece birinin (3 nolu olgu) kardeşlerinde ve babasında benzer bulgular mevcuttu, diğer olguların aile öyküsü yoktu. 
Tablo-1. Olguların klinik bulguları.

\begin{tabular}{|c|c|c|c|c|}
\hline & Olgu 1 & Olgu 2 & Olgu 3 & Olgu 4 \\
\hline Yaş & 49 & 20 & 23 & 39 \\
\hline Cinsiyet & Erkek & Erkek & Kadın & Kadın \\
\hline \multicolumn{5}{|l|}{ Bulgular } \\
\hline BHK & - & - & + & + \\
\hline Çene kisti & + & + & + & + \\
\hline Palmoplantar pit & - & + & + & + \\
\hline $\begin{array}{l}\text { Falx cerebri } \\
\text { kalsifikasyonu }\end{array}$ & + & + & + & - \\
\hline Bifid kosta & - & + & - & - \\
\hline İskelet anomalisi & $+($ polidaktili $)$ & $\begin{array}{l}\text { + (polidaktili, skolyoz, } \\
\text { fibröz kortikal defekt) }\end{array}$ & + (diş anomalisi) & + (diş anomalisi) \\
\hline Medulloblastom & - & - & - & - \\
\hline Ek bulgu & & Görme kaybı & Pilositik astrositom & \\
\hline
\end{tabular}

Tablo-2. PTCH1 geninde saptanan varyantlar ve özellikleri.

\begin{tabular}{lllll}
\hline Olgu & cDNA & Protein & Varyant tipi & Varyant durumu \\
\hline Olgu 1 & c.519delA & p.A174RfsX46 & Çerçeve kayması & Yeni \\
Olgu 2 & c.1766delT & p.L589RfsX34 & Çerçeve kayması & Yeni \\
Olgu 3 & c.3406G>C & p.G1136R & Yanlış anlamlı & Yeni \\
Olgu 4 & c.2561-2A $>$ G & IVS15-2A $>$ G & Kırpılma bölgesi & Tanımlı \\
\hline
\end{tabular}

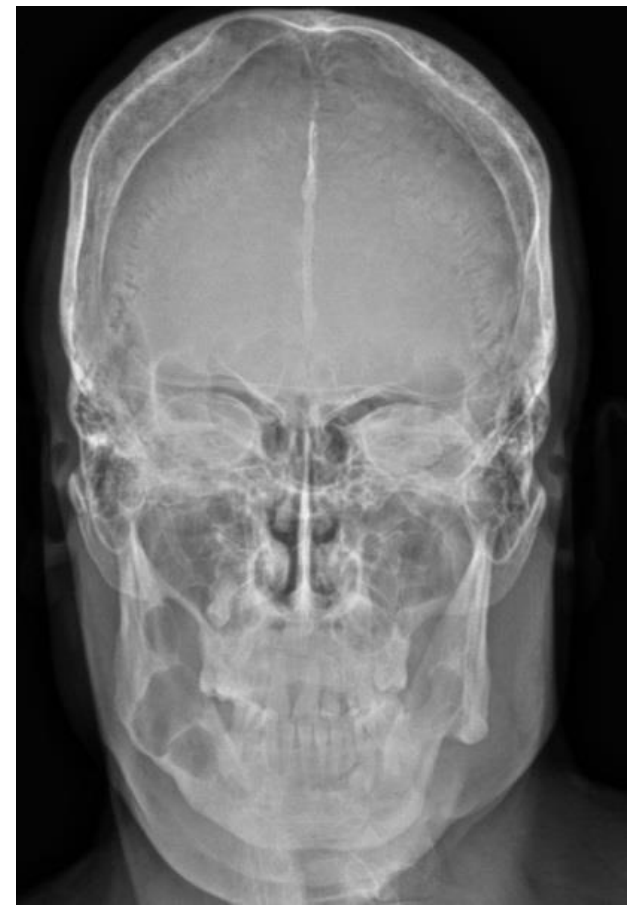

Şekil-1. Olgu 1'in AP kafa grafisi.
PTCH1 gen dizi analizi yapılan dört hastanın hepsinde farklı bir varyant saptanmıştır. Bu varyantlardan iki tanesi çerçeve kayması tipi (A174RfsX46 ve L589RfsX34), bir tanesi yanlış anlamlı tip (G1136R) ve biri de kırpılma bölgesi tipi varyanttır (IVS15-2A>G). Çerçeve kayması tip varyantlar 3. ve 13. ekzonlarda, yanlış anlamlı varyant 20. ekzonda ve kırpılma bölgesi 15 . intronda yer almaktaydı. Saptanan varyantlardan bir tanesi daha önce ClinVar veri tabanında bildirilmiştir. Diğer üç varyant ise yenidir. Yeni varyantlar in silico programlar ile değerlendirilmiştir. Tablo-2'de varyantların özellikleri gösterilmektedir. Segregasyon çalışmasında sadece 3 nolu olgunun babasında aynı varyant saptanmış olup diğer üç olgudaki varyantlar de novo olarak saptanmıştır.

\section{TARTIŞMA}

Bu çalışmada Gorlin Sendromu ön tanısı olan 4 olgu değerlendirildi ve $P T C H 1$ geninde 3'ü yeni 4 farklı varyant saptandı. Varyantlardan c.2561$2 A>G$ (IVS15-2A>G) daha önce ClinVar veri 
tabanında patojenik olarak tanımlanmıştı. Bu varyant, 15. intronun kırpılma bölgesinde yer almaktadır ve kırpılmayı bozucu etkiyle protein yapısını bozduğu öngörülmektedir. Saptanan üç yeni varyanttan ikisi çerçeve kayması yapan ve biri yanlış anlamlı varyantıdır. Bu değişiklik tüm in silico programlarca hastalık yapıcı olarak değerlendirilmiştir. ACMG kriterleri ile tanımlı olmayan varyantlar, A174RfsX46 ve L589RfsX34 "patojenik" ve G1136R ise "patojenik benzeri" olarak değerlendirildi. Literatüre bakıldığında PTCH1 genindeki varyantların dağılımı ile ilgili her hangi bir "hot spot" bölge olmadığı ve gen boyunca yayıldığı bildirilmiştir (15). Çalışmamızdaki varyantlar da önceki çalışmalarla uyumlu olarak genin farklı ekzon ve intronlarında saptanmıştır. Varyant tipi açısından bakıldığında Gorlin Sendromuyla ilişkilendirilen varyantlar en sık olarak çerçeve kaymasına yol açan varyantlar olup bu grup içinde de en büyük yüzdeyi küçük delesyonlar oluşturmaktadır (16). Bizim çalışmamızda da en sık saptanan (\%50) varyant tipidir. Veri tabanlarında ikinci sıklıkta yanlış anlamlı varyantlar ve üçüncü sıklıkta kırpılma bölgesi varyantları gelmektedir (16). Bizim çalışmamızda da her iki grup \%25 sıklıkla saptanmıştır.

Olguların kadın erkek oranı otozomal dominant kalıtımla uyumlu olarak 1:1 idi. Olguların hepsi, Bree ve ark.'nın 2011 yılında yayınladığı tanı kriterlerine uygundu. Olguların tamamında çenede kiste bağlı geçirilmiş operasyon öyküsü vardı. Kistlerin patolojilerine bakıldığında üç olguda keratokist ve bir olguda ise dentijeröz kist tanısı mevcuttu. Çene kistleri bu sendromda en sık bulgulardan (\%62-75) olmasına rağmen bizim çalışmamızda literatürden daha sık saptandı (\%100) $(15,17,18)$. Bazal hücreli karsinom ise \%25 ile literatüre göre (\%95) oldukça az saptandı $(9,17,18)$. Bu düşük oranın sebebi diğer üç hastadan ikisinin henüz 20'li yaşların başında olması olarak düşünüldü. Alonso ve ark.'nın çalışmasında BHK için ortalama tanı yaşı
28 olarak saptanmıştır (18). Literatürde ikinci sıklıkta görülen bulgu \%75 sıklık ile, falx cerebri kalsifikasyonudur. Evans ve ark.'nın çalışmasında falx cerebri kalsifikasyonunu \%76 sıklıkta bildirilmiştir ve bizim bulgularımızla benzerdir (9).

Gorlin Sendromu tanı kriterlerinde major bulgular arasında santral sinir sistemi tümörlerinden medulloblastom yer alır. Smith ve ark.'nın 2014'teki çalışmasında PTCH1 geninde mutasyon olanlarda medulloblastom riskini \%2'nin altında bildirmiştir (10). Bizim çalışmamızda hiçbir olguda medulloblastom öyküsü olmamakla birlikte, olgu 3'te serebellar pilositik astrositom öyküsü mevcuttu. Daha önceki yayınlarda Gorlin Sendromunda pilositik astrositom hiç tanımlanmamış olup ilk kez bizim çalışmamızda saptanmıştır.

Gorlin Sendromu ile ilgili önceki çalışmalarda polidaktili nadiren bildirilmiş olup minör bulgular arasında yer almasına rağmen çalışmamızda olguların \%50'sinde saptanmıştır. Veenstra-Knol ve ark. tarafından bildirilen olgulardan ikisinde polidaktili saptanmış ve her ikisinin de çerçeve kayması yapan birer varyant taşıdığı bildirilmiştir (19). Bizim çalışmamızdaki polidaktili olan her iki olgunun da çerçeve kayması varyantı taşıyor olması da fenotip-genotip korelasyonu katkı sağlaması açısından önemlidir.

\section{SONUÇ}

Sonuç olarak bu çalışma Türkiye'de Gorlin Sendromlu olgularda PTCH1 gen varyantlarının spektrumu ile ilgili yapılmış ilk çalışmadır. Çalışmada üç tanesi yeni tanımlanmak üzere dört farklı varyant saptanmıştır. Klinik bulgular ve mutasyon spektrumu ile fenotip-genotip korelasyonu açısından literatüre katkıda bulunmaktadır.

\section{Çıkar çatışması}

Çıkar çatışması yoktur.

\section{Kaynaklar}

1. Satinoff MI, Wells C. Multiple basal cell naevus syndrome in ancient Egypt. Med Hist 1969; doi: $10.1017 /$ S0025727300014563.

2. GORLIN RJ, GOLTZ RW. Multiple nevoid basal-cell epithelioma, jaw cysts and bifid rib. A syndrome. N Engl J Med 1960; doi: 10.1056/NEJM196005052621803.

3. Springate JE. The nevoid basal cell carcinoma syndrome. J Pediatr Surg 1986; 21:908-10.

4. Jones EA, Sajid MI, Shenton A, Evans DG. Basal Cell Carcinomas in Gorlin Syndrome: A Review of 202 Patients. J Skin Cancer 2011; 2011: 1-6. 
5. Bree AF, Shah MR. Consensus statement from the first international colloquium on basal cell nevus syndrome (BCNS). Am J Med Genet Part A 2011; 155: 2091-7.

6. Johnson RL, Rothman AL, Xie J, et al. Human homolog of patched, a candidate gene for the basal cell nevus syndrome. Science (80-) 1996; doi: 10.1126/science.272.5268.1668.

7. Pastorino L, Ghiorzo P, Nasti S, et al. Identification of a SUFU germline mutation in a family with Gorlin syndrome. Am J Med Genet Part A 2009; doi: 10.1002/ajmg.a.32944.

8. Fujii $\mathrm{K}$, Ohashi $\mathrm{H}$, Suzuki $\mathrm{M}$, et al. Frameshift mutation in the PTCH2 gene can cause nevoid basal cell carcinoma syndrome. Fam Cancer 2013; doi: 10.1007/s10689-013-9623-1.

9. Evans DG, Oudit D, Smith MJ, et al. First evidence of genotype-phenotype correlations in Gorlin syndrome. J Med Genet 2017; 54: 530-6.

10. Smith MJ, Beetz C, Williams SG, et al. Germline Mutations in SUFU Cause Gorlin Syndrome-Associated Childhood Medulloblastoma and Redefine the Risk Associated With PTCH1 Mutations. J Clin Oncol 2014; 32 : 4155-61.

11. Stone DM, Hynes M, Armanini M, et al. The tumour-suppressor gene patched encodes a candidate receptor for Sonic hedgehog. Nature 1996; doi: 10.1038/384129a0.

12. Durmaz CD, Evans G, Smith MJ, Ertop P, Akay BN, Tuncall T. A Novel PTCH1 Frameshift Mutation Leading to Nevoid Basal Cell Carcinoma Syndrome. Cytogenet Genome Res 2018; 154: 57-61.

13. Ozcan G, Balta B, Sekerci A, et al. A novel PTCH1 gene mutation in a pediatric patient associated multiple keratocystic odontogenic tumors of the jaws and Gorlin-Goltz syndrome. Indian J Pathol Microbiol 2016; 59: 335.

14. Ozlu E, Karadag AS, Akalın I, et al. Novel PTCH1 Gene Mutation in a Patient with Gorlin-Goltz Syndrome. Ann Dermatol 2019; 31: S10.

15. Boutet N, Bignon Y-J, Drouin-Garraud V, et al. Spectrum of PTCH1 Mutations in French Patients with Gorlin Syndrome. J Invest Dermatol 2003; 121: 478-81.

16. HGMD database. http://www.hgmd.cf.ac.uk/ac/index.php. Acce- n.d.

17. Kimonis VE, Goldstein AM, Pastakia B, et al. Clinical manifestations in 105 persons with nevoid basal cell carcinoma syndrome. Am J Med Genet 1997; 69: 299-308.

18. Alonso N, Cañueto J, Ciria S, et al. Novel clinical and molecular findings in Spanish patients with naevoid basal cell carcinoma syndrome. Br J Dermatol 2018; 178: 198-206.

19. Veenstra-Knol HE, Scheewe JH, Van Der Vlist GJ, Van Doorn ME, Ausems MGEM. Early recognition of basal cell naevus syndrome. Eur J Pediatr 2005; doi: 10.1007/s00431-004-1597-4. 